\section{Transgenes are revolutionizing crop production}

\section{George Bruening}

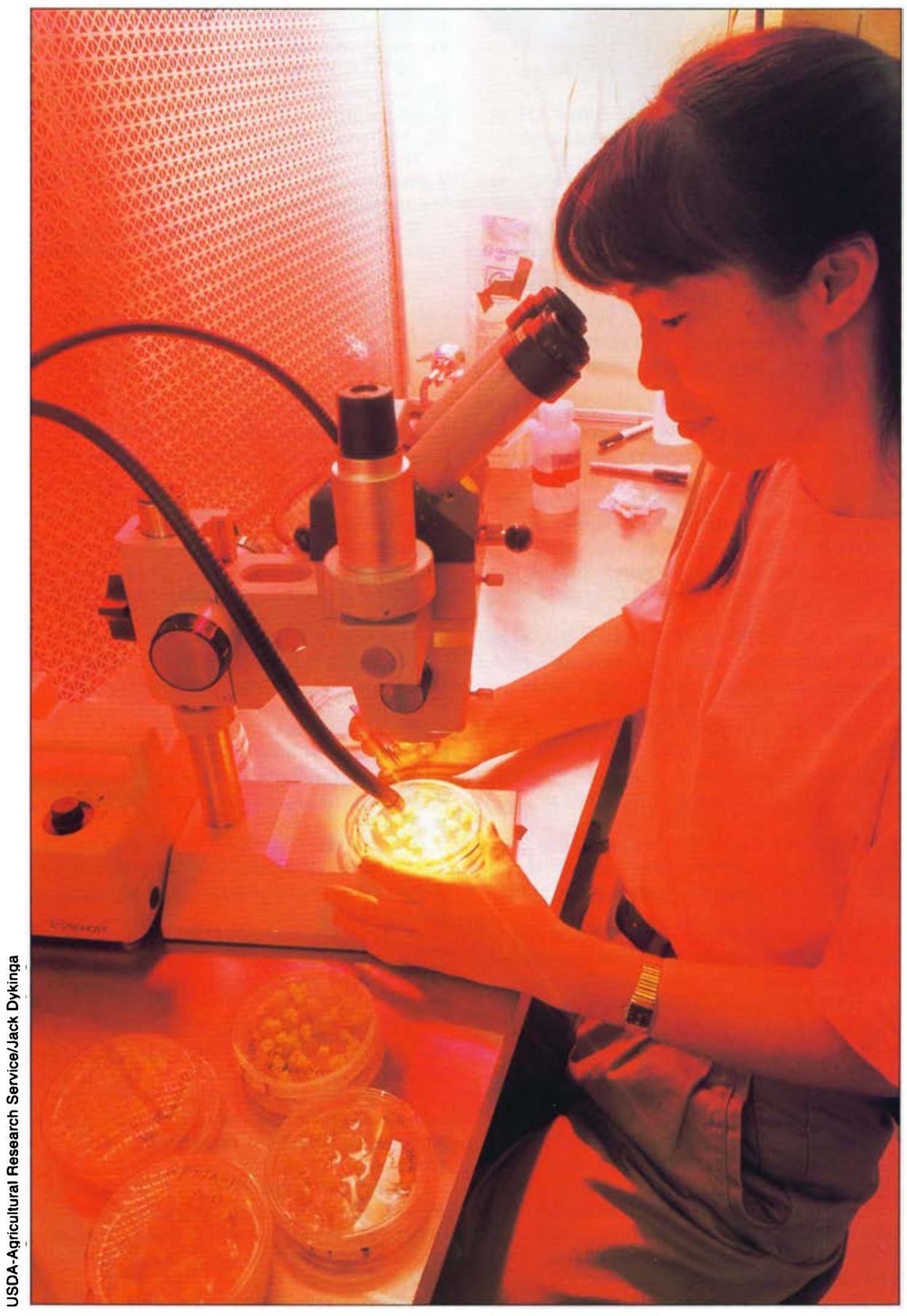

The most recent biotechnology revolution in crop agriculture began in the mid-1980s, based on in vitro cutting and joining of DNA and plant-tissue culture methods.

Yuechun Wan transfers plant cultures at the UC Berkeley department of microbial and plant biology.
The ability to cut and join DNA to create a new molecule and to insert into the crop plant the new DNA molecule as a new gene, a "transgene," forms the basis of the most revolutionary crop improvement technology of the 20th century. The bulk of crop transgenes thus far commercialized were designed to aid in crop protection against insects and weeds. The first commercial introduction of transgenes into field crops occurred in 1996. By 2000 in the United States, transgenic soybean and cotton accounted for more than half the area planted to these crops. Cotton accounts for virtually all current transgenic crop planting in California. This article compares transgene-based and conventional pest and weed control for potential in improving food production, food safety and environmental quality. The capabilities of recently developed technologies suggest that the first decades of the 21st century will see additional, and more dramatic, improvements in agronomic traits through use of transgenes, new chemical control methods, and enhanced integration of new technologies into various farming systems.

Tnder a broad definition, biotechnology is concerned with the manipulation of living systems to create useful products and services. Crop agriculture is a collection of biotechnologies. In prehistoric times, the nonsystematic selection of favorable planting materials presumably resulted in gradual adaptation of crop plants to meet the multiple needs of early agricultural groups. There also is evidence of more directed efforts to create crop plants with specialized characteristics. Rice breeding for dwarfism may have been practiced in China 1,400 years ago, with a concomitant increase in harvest index, the ratio of harvested grain mass to mass of aerial plant parts, on a dry weight basis (Han 1987).

Beginning in the 19th century, but most apparent in the 20th century, 
high output crop production was achieved by using fossil fuels and systematically developing and applying farm machinery, plant breeding, pesticides, herbicides, fertilizers, plant growth substances, and water and pest management techniques. In grain production, significant gains in productivity have been associated with improved harvest index. Improved harvest index in turn is associated with improved nitrogen utilization, which is considered to be the engine of the green revolution (Sinclair 1998).

Wide genetic crosses have been practiced from early in the 20th century. However, in the 1940 s plant breeding took a step well beyond Mendel when ovule or embryo rescue was developed as a tissue culture method, allowing crosses between species that otherwise would not be possible, typically between species of one genus or of closely related genera. This technology remains very useful for moving disease resistance and other valuable traits into cultivars from wild relatives.

Disease resistance and other valued traits also have been developed by mutagenesis, induced by chemicals and radiation. A few thousand cultivars have been developed with inputs from wide crosses and mutagenesis (van Harten 1998; Fedak 1999). Enzymes that remove plant cell walls were discovered, allowing cell-wall-less cells, "protoplasts," to be generated. A critical technical advance was the regeneration from single protoplasts of intact plants. Most regenerated plants are unchanged from the parental line, but significant and useful variation, "somaclonal variation" also may be seen. Chemical treatments that fuse protoplasts allow transfer of genetic material between species. Protoplast fusion drastically alters the assembly of genes that forms the plant genome, being capable of creating not just a new cultivar but a new plant species.

\section{Modern crop biotechnology}

The most recent biotechnology revolution of crop agriculture began in the mid-1980s, based on in vitro cutting and joining (in vitro recombina-

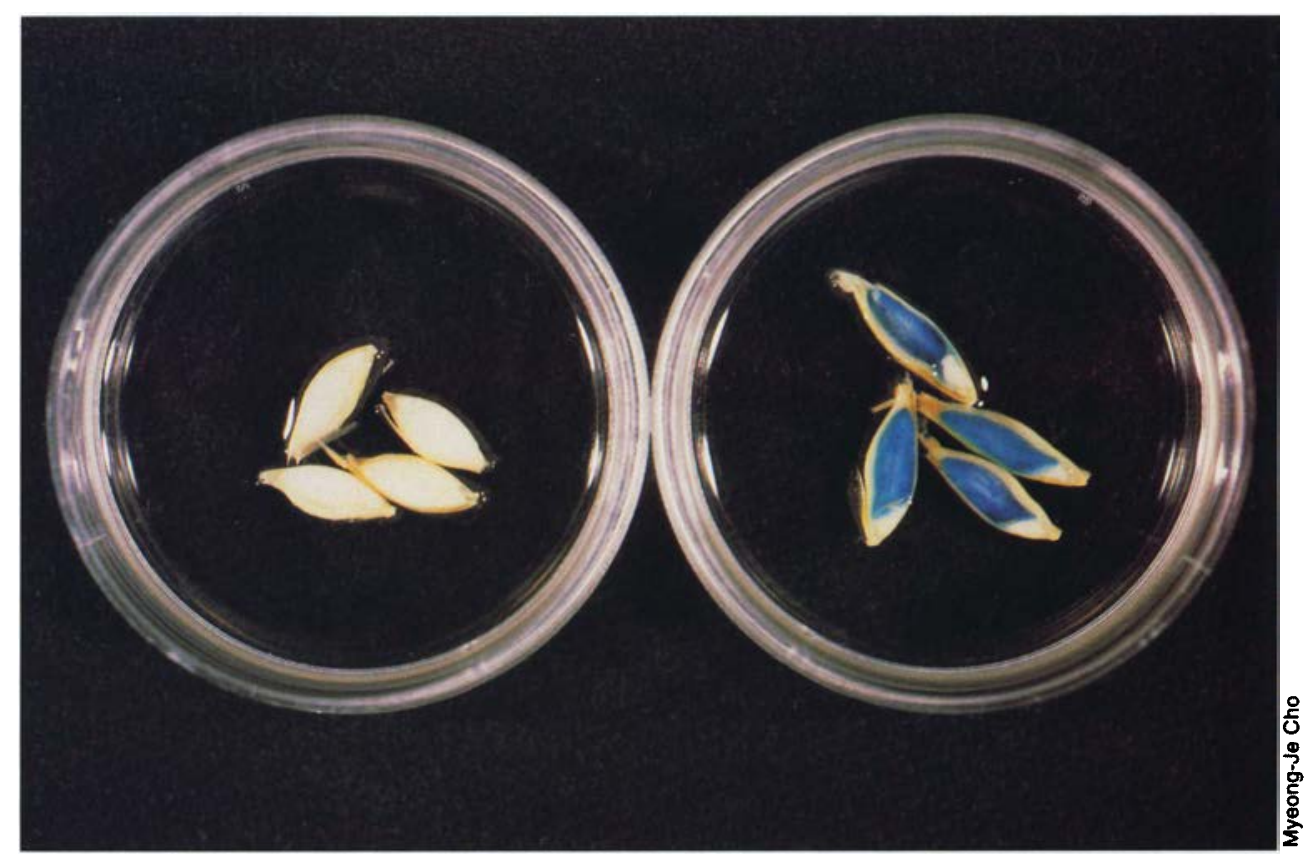

tion) of DNA and plant tissue culture methods. The result is a "recombinant DNA" (rDNA) or "transgenic" crop plant, also known as a genetically engineered (GE) or genetically modified organism (GMO). GMO is a widely accepted but misleading term, because it is a

biological reality that all crop plants are "genetically modified" by the selection processes humans have applied to them. However, rDNA methods provide broad capability for the sources of new genes. In laboratory experiments, DNA from plants, bacteria, other microorganisms and animals, and even chemically synthesized DNA, have been incorporated into plant cells and protoplasts by rDNA methods to create new transgenes in experimental crop plant lines. New and valued traits have been created that likely could not have been developed by more traditional methods.

To date, the great majority of commercialized crop transgenes confer improved agronomic traits rather than

\section{Of the crop technologies developed in the 20th century, transgenic plants have the greatest potential for making quantum improvements in crop
productivity.}

Scientists are working to confer specific valued traits into crop plant lines derived from single transformed cells. Top, In Peggy Lemaux's laboratory at UC Berkeley, a blue protein is made exclusively in barley endosperm. Using fluorescent in situ hybridization, scientists can visualize the location of particular genes on particular chromosomes. Above, Arrows point to genes on two identical chromosomes.

. 


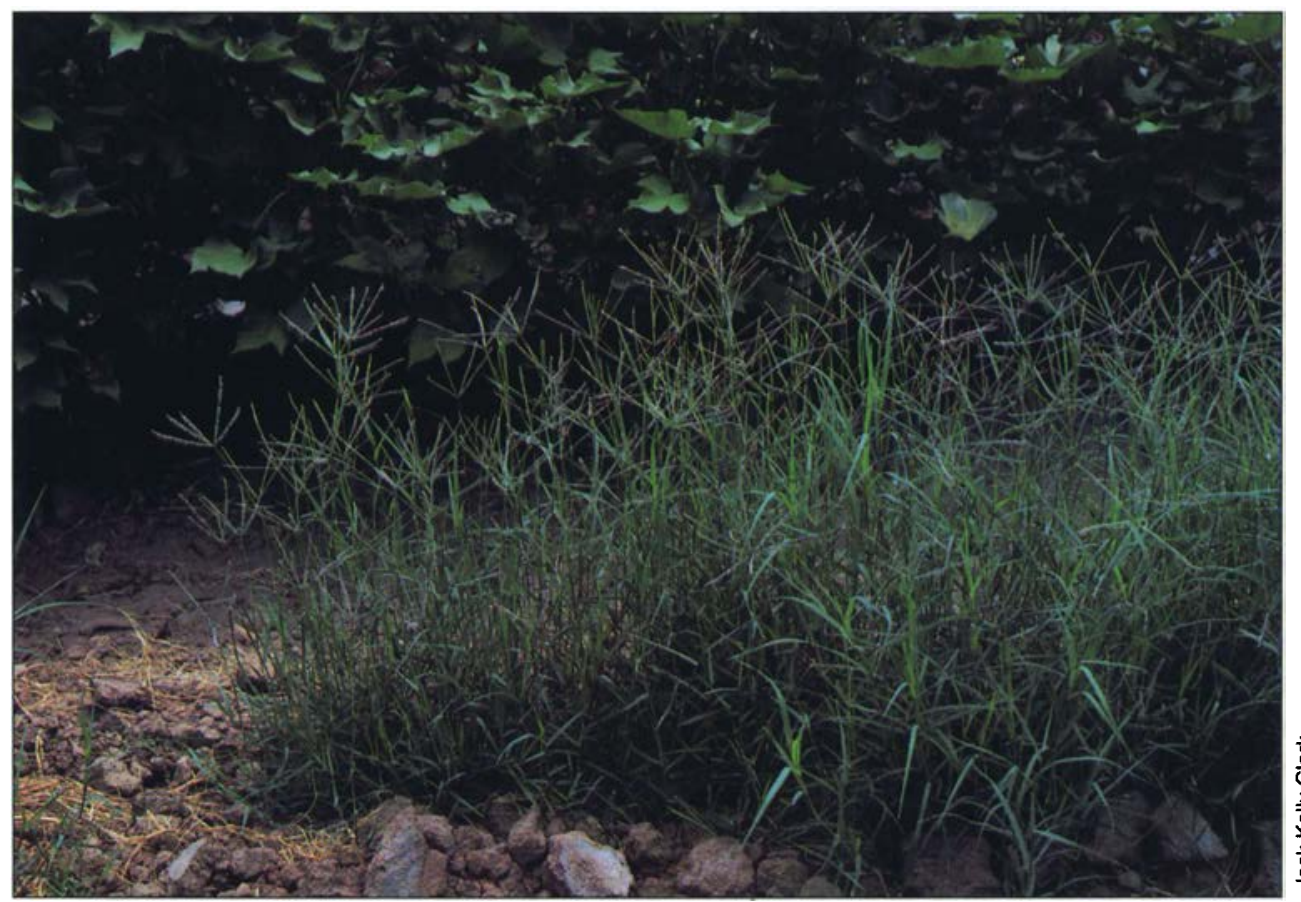

Herbicide-tolerant crops make It possible for growers to spray for weeds without destroying the crop. Bermudagrass is often difficult to control.

traits directly influencing the quality of the crop product. Worldwide, the area planted to transgenic crops in 1999 was more than 97 million acres (39 million hectares) (Ferber 1999; James 1999). Herbicide tolerance traits, principally to glyphosate (Roundup), accounted for about three-fourths of the planted area, and $30 \%$ of the area was planted to insect-resistant crops. Crops expressing both herbicide tolerance and insect resistance were planted in more than $7 \%$ of the area. Resistance against specific viruses also has been commercialized but accounted for less than $1 \%$ of the planted area in 1999.
According to U.S. Department of Agriculture (USDA) surveys of growers, plantings of transgenic cotton and soybean have increased each year since 1996 , reaching $61 \%$ and $54 \%$ of the U.S. acreage in 2000 (USDA 2000). Year 2000 transgenic corn acreage declined from the 1999 level. Production considerations, such as expected levels of insect infestation, likely dominated over considerations of export markets in decisions to reduce transgenic corn planting. In fiscal year 1998/1999, $7.5 \%$ of U.S. soybean production, but only $0.7 \%$ of U.S. corn production, was exported to the European market, the market showing the greatest sensitivity to GMO issues (Ballenger et al. 2000). Growers' stated reasons for adoption of transgenic crops include expectations of higher yields, reduced pest management costs and greater flexibility in cropping practice (Fernandez-Cornejo and McBride 2000). In descending order, the five crops with the largest proportion of transgenic planting are cotton, soybean, corn, rapeseed and potato.

\section{Transgenic crops in California.}

Among the commercialized transgenic crops, only cotton has had a significant impact in California. Cotton ranks second among California crops, after al-

TABLE 1. Comparison of applications of traditional pesticides with accumulation of transgenic pesticidal-protein

\begin{tabular}{|c|c|c|c|c|c|c|c|c|}
\hline & \multirow[b]{2}{*}{$\begin{array}{l}\text { Pesticidal- } \\
\text { protein** }\end{array}$} & \multirow[b]{2}{*}{$\begin{array}{l}\text { Traditional } \\
\text { pesticide } \\
\text { totalt }\end{array}$} & \multicolumn{6}{|c|}{ Traditional pesticides } \\
\hline & & & $\begin{array}{l}\text { Non-sulfur } \\
\text { fungicides, } \\
\text { bacteriocides }\end{array}$ & Sulfur & $\begin{array}{c}\text { Non-oil } \\
\text { insecticide }\end{array}$ & Oil & $\begin{array}{c}\text { Methyl } \\
\text { bromide }\end{array}$ & Otherf \\
\hline \multicolumn{9}{|l|}{ Apricots } \\
\hline$g$ a.i. $/ \mathrm{kg}$ harv. $\S$ & 0.028 & 3 & 1.0 & - & 0.36 & 1.67 & 0.26 & - \\
\hline kg a.i./ hectare & 0.34 & 27 & 8.5 & - & 3.0 & 14 & 2.2 & - \\
\hline \multicolumn{9}{|l|}{ Carrots } \\
\hline g a.i./ kg harv. & 0.021 & 2 & 0.1 & 0.23 & 0.03 & - & 0.58 & 1.22 \\
\hline$k g$ a.i./ hectare & 1.3 & 78 & 3.9 & 8.4 & 1.25 & - & 21 & 44 \\
\hline \multicolumn{9}{|l|}{ Grapes } \\
\hline g a.i./ kg harv. & 0.013 & 12 & 0.32 & 10.1 & 1.05 & 0.046 & 0.53 & 0.008 \\
\hline kg a.i./ hectare & 0.5 & 203 & 5.4 & 170 & 18 & 0.77 & 8.9 & 0.14 \\
\hline \multicolumn{9}{|l|}{ Lettuce } \\
\hline g a.i./ kg harv. & 0.026 & 1.0 & 0.4 & - & 0.38 & - & 0.13 & - \\
\hline $\mathrm{kg}$ a.i./ hectare & 1.5 & 33 & 12 & - & 12 & - & 4 & 5 \\
\hline \multicolumn{9}{|l|}{ Peaches } \\
\hline g a.i./ kg harv. & 0.014 & 6.4 & 3.9 & 0.38 & 0.65 & 0.98 & 0.48 & - \\
\hline kg a.i./ hectare & 0.8 & 191 & 117 & 11 & 19 & 29 & 14 & - \\
\hline \multicolumn{9}{|c|}{$\begin{array}{l}\text { - Calculations of values based on estimated protein content in grams per kilogram of harvested product (first entry under each crop heading) and the estimated } \\
\text { kilograms of whole plant protein accumulated in one growing season, per hectare (second entry). The transgene protein active ingredient is taken to be } 0.2 \% \text { of the } \\
\text { total protein amount. } \\
\text { t This column reports the sum from subsequent columns for each row (Gianessi and Anderson 1995). } \\
\text { f Non-methyl bromide soil sterilizers and miscellaneous. } \\
\$ \text { g a.i./kg harv. = grams of active ingredient accumulated or applied per kilogram of harvested product; kg a.i./hectare = kilograms of active ingredient accumulated } \\
\text { or applied per hectare. } \\
\text { Sources: Williams 1996; Davis et al. 1999; Gianessi and Anderson 1995; Grossman 1993; Haytowitz and Matthews 1984; Gebhart et al. } 1982 \text {. }\end{array}$} \\
\hline
\end{tabular}


falfa, in area planted and harvested (Pease et al. 1996). Less than 1,000 acres of transgenic, herbicide-tolerant cotton were planted in California in 1997, mostly as experimental plots (Vargas and Wright 1998). However, for the 2000 season, industry sources, Madera County farm advisor Ron Vargas (personal communication), and USDA survey data indicate that about $24 \%$ (225,600 acres) of the California cotton crop was planted with lines containing transgenes for herbicide tolerance (glyphosate or bromoxynil), insect resistance, or both.

Whether and when transgenic field, vegetable, orchard and vineyard crops become a significant part of California agriculture depends on a variety of factors. Among these are cooperation by holders of intellectual property rights, the extent of economic benefit to growers and consumers, food quality improvements, and national and international public acceptance of transgene technology. Any legitimate ecological and food safety issues related to various transgenic crops must, of course, be satisfied.

\section{Transgene-based and traditional pest control}

For five selected California crops, table 1 presents the amounts of pesticide active ingredients applied in production. Among all California crops, the largest total amount of pesticide is applied to grapes, while peaches rank eighth. In the amount of pesticide applied per acre, grapes, peaches and carrots rank fourth, eighth and ninth (Pease et al. 1996). For a transgenic crop, the transgene directs the synthesis of a new protein, which acts against the target pest or pathogen and may be regarded as the "active ingredient." The U.S. Environmental Protection Agency (U.S. EPA) has taken the authority to regulate such a transgenic crop because the plants are considered to contain a "pesticidal-protein." Although expression levels corresponding to up to $2 \%$ of the cell protein have been observed under special experimental conditions, usually transgene expression in commercialized crops is in the range $0.01 \%$ to $0.1 \%$ of total cell protein. Table 1 compares conven-

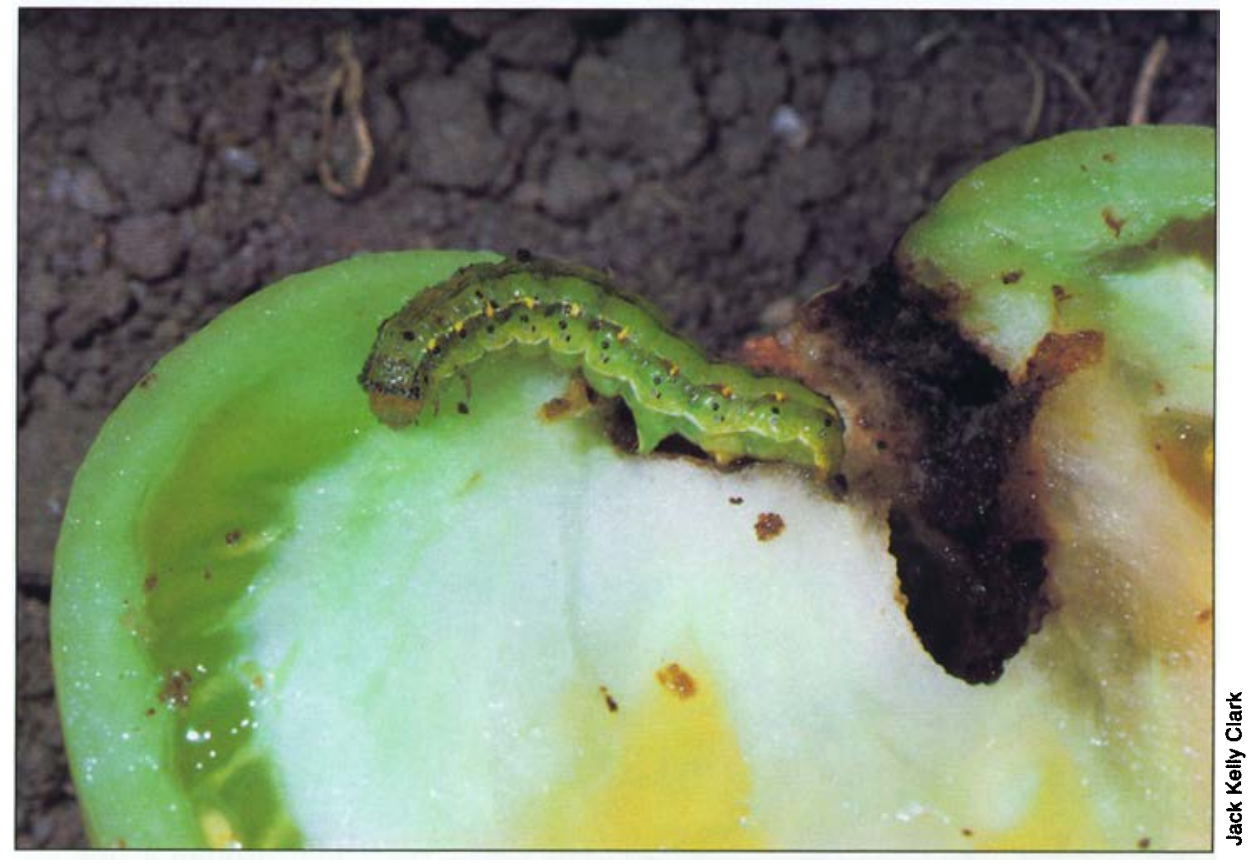

tional pesticide totals with the expected accumulation of transgene-expressed pesticidal-protein, assuming that $0.2 \%$ of the protein in all parts of the crop plant will be pesticidal-protein.

Several transgenes presumably would be required to confer protection against most of the important pests

and pathogens of a crop. Even for several simultaneously expressed transgenes, the calculated mass of pesticidal-protein is small compared to the mass of chemicals applied in current practice (table 1). A pesticidalprotein has a molecular weight of tens of thousands, compared to a molecular weight of at most a few hundred for typical chemical pesticides. On the basis of the number of molecules of agent, rather than mass of agent, the amount of pesticidal-protein accumulated in the field during a growing season is miniscule compared to the number of molecules of chemicalagent active ingredient currently employed. Transgene-specified plant pesticidal-proteins continue the present trend toward reduced dose that is seen for conventional pesticide applications.
Bacillus thuringiensis is the only commercialized transgene for protecting crops against insects, such as the corn or tomato earworm, top. Nematodes that cause root galling in lettuce, above, could also be targeted by transgene biotechnology.

The type of agronomic trait conferred by the transgene, whether herbicide tolerance, insect resistance, cold tolerance or other characteristic, is generally, but not always, a consequence of the synthesis of a new protein or an increase or decrease in the synthesis of an endogenous protein. In theory, changes in the synthesis or accumulation of specific proteins (i.e., changes in "protein expression") or other consequences of the transgene could result in changes in the crop plant or its products that may be distinct from the intended trait, with pos-

\section{Regulation of transgenic crops}




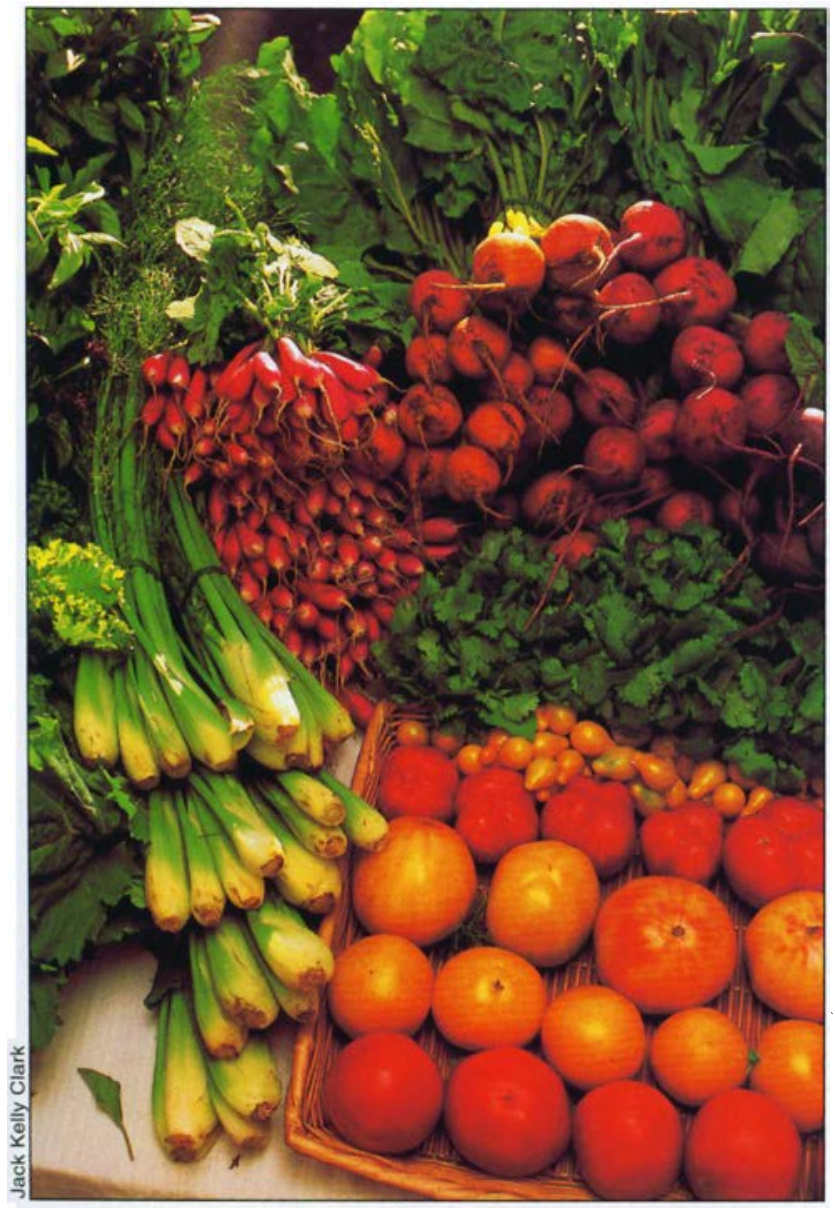

Callfornia's specialty crops are not, at present, transgenic. Whether transgenic crops become a significant part of agriculture will depend on factors such as cooperation by holders of intellectual property rights, the extent of economic benefit to growers and consumers, food quality improvements, and public acceptance of transgene technology.

sible implications for food safety and environmental effects. These are issues that are considered during the registration process, which is specific to the transgene, the crop and the area in which the crop may be planted. Registrations of transgenic crops often are for a specified period, e.g., 5 years.

Environment. Developers of transgenic crops submit to the U.S. EPA data for estimating a "no observed effect concentration" (NOEC) for specified nontarget organisms. To obtain an estimate of the NOEC, developers must add purified pesticidalprotein, for example to a bird or mammalian test diet, because the amount of pesticidal-protein in the transgenic plant tissue is far below the NOEC. Often in these tests the NOEC is not reached because insufficient pesticidal-protein is available. No significant unintended effect of a commer- cialized transgenic crop has been detected, including no significant toxicological consequences in birds or mammals. Possible consequences of gene transfer to noncrop plant species, of possible toxicological effects on nontarget insects, and of possible resistance development in target insects, are considered below in the context of specific transgenes.

Table 2 summarizes some qualitative and quantitative differences between conventional pesticides and plant pesticidal-proteins. A pesticidal-protein is not transported from manufacturer to the site of application in a concentrated and hence more dangerous form. There is no requirement for dilution and application of a pesticidalprotein on site, and it will not be sprayed into air or water. Instead, the "pesticide application" process consists of planting seeds, containing the transgene or very small amounts of the pesticidal protein. Stability in the environment is required for the effectiveness of some chemical agents. In contrast, the environmental stability of a pesticidal-protein would be expected to be like that of a typical protein: very low in soil or water because proteins are food for a great variety of organisms during the decay process. Those characteristics of plant pesticidal-proteins and of conventional chemical pesticides considered to be advantageous to each group are presented in the yellow-shaded areas of table 2.

Food safety. The registration and consultation process before commercialization of a transgenic crop typically involves USDA, the U.S. EPA, and the U.S. Food and Drug Administration. Regulators strive to identify any material differences between the transgenic cultivar and corresponding nontransformed cultivars. They consider both agronomic and quality traits through data requirements based on diverse aspects of phenotype testing. Even aspects unlikely to provide any perceptible risk, for example location of the transgene in the cultivar genome and possible alterations in plant metabolism, are addressed by phenotype testing.

Both transgenic crop registration and pesticide registration consider pesticide residues in food. Washing procedures and prohibitions on the use of the agent during specified periods prior to harvest generally limit conventional pesticides to trace or undetected levels in food (table 2). The internally synthesized pesticidalprotein may be present in and retained by the harvested food from a transgenic crop, but at a level far below the NOEC.

The general public acceptance of crops derived from the older genetic improvement methods and the more limited acceptance of transgenic crops is not consistent with the greater extent of genetic changes introduced into the cultivar by the older methods. The nontransgene methods of wide genetic cross or protoplast fusion, followed by extensive backcrosses to the cultivar, typically retain in the cultivar tens or hundreds of unknown genes from the wild relative parent. These genes specify unknown and undocumented proteins derived from a plant that may be inedible or even the source of poisonous fruit that certainly would not be approved for human consumption. Typically none of these unknown proteins has been or could be, at this time, directly tested, such as for digestibility under conditions found in the human stomach. Proteins that resist digestion are candidate allergenic proteins. The unknown proteins introduced in a wide cross are encoded by tens of thousands of unspecified nucleotides, a nucleotide being the smallest unit of genetic determination.

In contrast, a crop plant transgene is defined at the single nucleotide level. Proteins encoded by the transgenes routinely are tested for digestibility and allergenicity. The transgene proteins now employed in commercialized transgenic crops have no known allergenic effect and have not been found to affect feeding value (Sidhu et al. 2000). For both conven- 


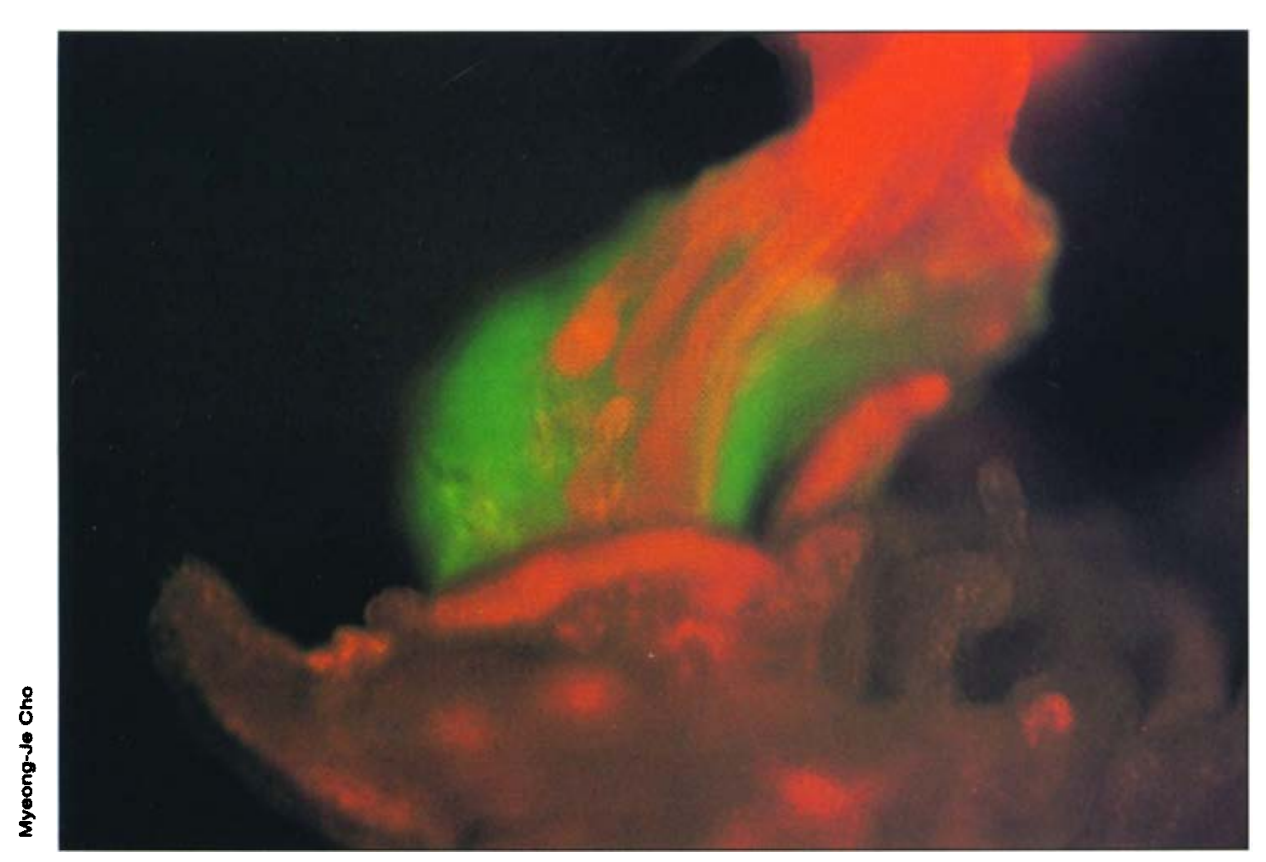

tionally bred and transgenic cultivars, adverse traits occasionally are found during phenotype testing. A transgenic soybean line expressing a Brazil nut protein, a line never intended as a source of human food, was withdrawn by the developer before commercialization when that protein was shown to be allergenic.

\section{0th-century commercialized transgenes}

Crop protection against insects. Worldwide, between $20 \%$ and $30 \%$ of crops are lost to insect damage. The cost of chemical and other control measures aimed at reducing insect damage is estimated at $\$ 10$ billion actual environmental costs of traditional synthetic insecticide applications are well known (Pimentel and Raven 2000). An alternative, the biologically based insecticides, including sprays of the bacterium Bacillus thuringiensis (Bt), have been used commercially since the late 1930 s. The Bt toxin, which is a protein in the bacterial preparations, confers resistance against insects of specific groups by binding to and acting on specific sites in the insect gut. (Estruch et al. 1997). The potential and
A fluorescent jellyfish gene has been engineered into oat to assist scientists in pinpointing where genes are expressed. Green areas are where the jellytish protein is made, while red is the sheath from which the seedling emerges.

Bt sprays have been largely displaced in conventional crop agriculture by modern insecticides, such as the synthetic pyrethrins, but Bt sprays continue to serve organic farming (Beegle and Yamamoto 1992). Researchers modified the Bt gene from $B$. thuringiensis to make it compatible with plant protein synthesis and introduced it as a transgene into various crop plants. At this time Bt is the only commercialized transgene for protection of crops against insects. Consistent with the presentation in table 1 , expression levels for various Bt proteins have ranged from $0.003 \%$ to $0.2 \%$ of total plant protein (Iannacone et al. 1997). Exposure of people to the $\mathrm{Bt}$ pesticidal-protein obviously predates transgene technology, both as a natural contaminant from bacteria on vegetables and as sprayed Bt insecticide.

There have been only a few interpretations of economic data with the intent of assessing the impact of transgenic crops. An estimate for Btcotton in 1996, its first year of introduction, suggests significant economic benefit to cotton growers in Alabama, Georgia, Mississippi and South Carolina, but less favorable and even unfavorable results attributed to the $\mathrm{Bt}$ trait

TABLE 2. Characteristics of conventional pesticides and plant pesticidal-proteins

Note: Yellow-shaded areas are advantageous characteristics

Conventional pesticides
Generally 0.1 to $10 \mathrm{~g}$ applied per $\mathrm{kg}$ of harvested crop product

Transported and stored in concentrated form to and at farm site Biodegradability varies greatly from agent to agent

Often released into the air and/or soil and water

Effectiveness may be reduced by development of insect resistance or herbicide tolerance

Typically low specificity for target organism(s); intermediate specificity achieved at a higher cost

Use limitations and washing procedures prescribed by limit residues to trace levels

Plant pesticidal-proteins

Generally less than $0.03 \mathrm{~g}$ accumulated per $\mathrm{kg}$ of harvested crop product

Synthesized on site as crop grows Readily biodegradable

Largely confined to plant tissues, at least during the growing season

Effectiveness may be reduced by development of insect resistance or herbicide tolerance

High specificity for target organism is readily achieved

Present in all plant cells in which pesticidal-protein is expressed and hence not readily removed or destroyed; inactivated in production of some processed foods

Replicated at cell division in the crop plant or other plant to which the gene may be transferred inadvertently 


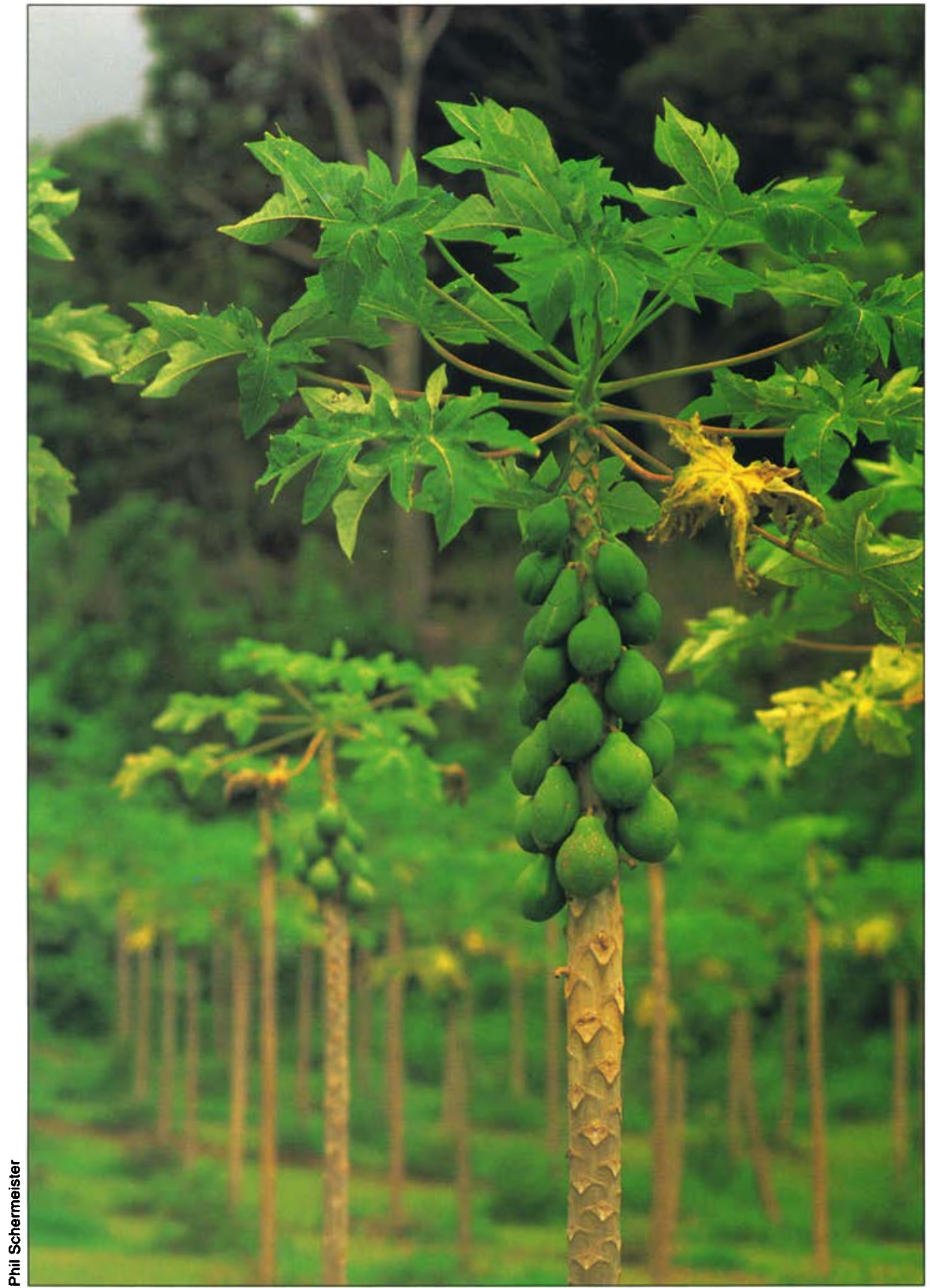

The introduction of transgenic cultivars has restored the papaya industry in Hawaii, which was virtually destroyed by papaya ringspot virus.

in some other cotton-growing areas, in part due to lesser insect problems. Overall, the economic benefit from Btcotton, relative to nontransgenic cotton, was estimated to be more than $\$ 200$ million in 1996 nationwide.

Growers were considered to have received $40 \%$ to $60 \%$ of this benefit, the developers and marketers of the technology $25 \%$ to more than $40 \%$, and consumers under $10 \%$. There were substantial reductions in applications of conventional insecticides in several cotton-growing areas, suggesting environmental as well as economic ben- . efits from introducing Bt-cotton that have continued into subsequent years (Traxler and Falck-Zepeda 1999; FalckZepeda et al. 2000; Fernandez-Cornejo and McBride 2000).

When introduced into corn, Bt transgenes have proved to be effective against insects such as the European corn borer (ECB), Ostrinia nubilalis, which has resisted control by all types of sprayed insecticides. Reduction in ECB infestation had a significant side benefit, reducing accumulation of the hazardous mycotoxin fumonisin, a product of certain Fusarium fungal species spread by the ECB (Munkvold et al. 1999). The economic benefits from Bt corn, as those from Bt cotton, vary with geographic area, due to factors such as probability of infestation by the ECB and profit margins (Hyde et al. 1998).

Possible insect resistance to $\mathrm{Bt}$. Insects are known to develop tolerance for, or resistance against, conventional insecticides. The possibility of insects developing resistance against $\mathrm{Bt}$ due to widespread and season-long deployment of Bt transgenes is a frequently raised objection to the Bt technology, particularly by organic growers (see p. 26). Only one insect, the diamondback moth, Plutella xylostella, has developed genetic resistance under field conditions against sprayed Bt. However, numerous studies have reported resistant insect lines appearing under strong selection in the laboratory (Frutos et al. 1999).

The most widely accepted approach for delaying the appearance of resistant insect lines is the "high-dose/refuge" strategy. If a mutation occurs in an insect that provides some protection against $\mathrm{Bt}$ toxin, the mutated gene will reside on only one chromosome of a chromosome pair. In later generations descended from such an insect, both chromosomes of a pair might bear the mutant gene, providing more substantial protection against Bt toxin. Under the high-dose/refuge strategy, most insects bearing one copy of the mutant gene are killed when they feed on crop plants expressing Bt toxin at a high level. A refuge of susceptible plants is provided to support populations of fully susceptible insects lacking the mutant gene. Matings between insects lacking the mutation and insects bearing two copies of the mutant gene will give offspring that bear only one copy, and therefore are susceptible to killing by Bt. If insects lacking the mutation are present in sufficient numbers due to the refuge, appearance in the next generation of insects with two copies of the mutant gene becomes very unlikely. The Bt crop registration specifies the refuge size and other characteristics for a given crop system, geographic area and types of crops grown in the same area. There is 
extensive debate about whether refuges sufficiently large and dispersed to be effective will be economically viable (Roush 1997; Tabashnik et al. 1999).

The yet-to-be-observed insect resistance to transgenic Bt could be combated by using alternative $B t$ genes concomitantly or serially. Many Bt proteins have been identified, distinguished by their molecular targets and specificity for different groups of insects. Only four Bt toxin types have been commercialized as transgenes in crop plants, but more than 20 types have been approved or are pending approval, and many more have been subject to laboratory trials (Frutos et al. 1999).

Possible nontarget insect effects. The larvae of butterflies and certain other nontarget insects do not feed on the transgenic crop plant, but would be expected to suffer toxic effects if exposed to sufficient amounts of Bt protein. One laboratory study confirmed that artificially large doses of pollen from Bt transgenic corn are toxic to monarch butterfly larvae (Losey et al. 1999). A field study showed no effect on swallowtail butterfly larvae from Bt transgene pollen at densities equal to and 50 times greater than those actually encountered near corn fields (Wraight et al. 2000). Factors influencing possible toxic effects on nontarget insects include the susceptibility of specific larvae, the concentration of $\mathbf{B t}$ protein in the pollen from specific corn lines, and the density of pollen accumulating near corn fields on plants supporting larvae populations. Conventional pesticides kill tens of millions of birds and billions of nontarget insects. For this reason, adoption of $\mathrm{Bt}$ crops is expected to provide a net benefit to nontarget insects such as the monarch butterfly (Pimentel and Raven 2000).

Herbicide-tolerant crop plants. Herbicides account for about twothirds of the agricultural chemicals sold. Transgenic herbicide tolerance is accomplished by expression of an altered and herbicide-resistant form of the protein that is the usual herbicide target, or by high level over-expression of the herbicide target protein, or by ex- pression of an enzyme that degrades the herbicide (Tsaftaris 1996). Planting a cultivar that is tolerant to being sprayed with a general purpose, readily degraded herbicide such as glyphosate alters the crop weed control strategy. The grower need not make preemptive strikes by herbicide spraying before emergence of transgenic crop seedlings but may wait and determine whether weeds are in fact a problem. After emergence, there is no need to use highly selective and often expensive, and perhaps environmentally unfriendly, herbicides. Tillage may be reduced, thereby saving on fuel, labor costs and soil erosion.

Critics of herbicide-resistant transgenic crops, in addition to their general objection to applications of crop transgene technology, express concern about possible increased herbicide use, about possible evolution of the herbicide-tolerant crop species into a weed, and about possible transfer of herbicide tolerance to weedy species. Preliminary studies suggest that the introduction of glyphosate-tolerant soybean and cotton resulted in a decrease in application of selective, potentially water-contaminating herbicides (Fernandez-Cornejo and McBride 2000). Weeds generally are characterized by a set of many traits that allow them to be highly competitive or otherwise present a problem in agricultural or natural settings. Insertion of a single transgene is unlikely to convert a crop plant into an effective weed. Potential for transfer of herbicide tolerance to weedy relatives of the crop plant is an important factor considered in the transgenic crop registration process, sometimes dictating restrictions on the geographic areas in which planting of the transgenic crop is allowed. (Known and unknown genes introduced into cultivars by wide genetic crosses also may be transmitted to wild relatives, but no submission of relevant data is required before commercialization of conventionally bred crops.) New technologies that reduce or eliminate the possibility of gene transfer from the crop plant to other plants will influence future considerations of this issue.
Virus-resistant crop plants. Transgenic control of virus infections has thus far found only limited applications. The transgenic approach of "pathogen-derived resistance" or more specifically "virus-derived resistance" may seem counterintuitive, because it proposes incorporating a gene or gene fragment of the target virus into the host plant DNA with the intent of conferring resistance against that target virus. Pathogen-derived resistance was first practiced against a plant virus by Roger Beachy and colleagues at Washington University and Monsanto Company, in St. Louis, when they transformed tobacco plants with a gene designed to express the coat protein of Tobacco mosaic virus (TMV) at high levels (Powell-Abel et al. 1986). Inoculating TMV to the transgenic, coat protein-expressing tobacco plants resulted in a reduction of the number of TMV infection sites to $0.1 \%$ or less of the control number, which was more than adequate to provide field resistance against TMV.

The coat-protein protection technology is employed in the papaya industry of Hawaii to prevent the devastating effects of papaya ringspot virus (PRSV) (Gonsalves 1998). PRSV is a serious threat to papaya production wherever this fruit is produced (Brazil, Taiwan, Thailand, and Hawaii) and had all but eliminated papaya production in Hawaii. Introduction of transgenic papaya restored the industry. A distinct transgene technology for conferring resistance against specific viruses has been commercialized in China based on use of a plant-virus parasite known as "satellite RNA" (Tien and Wu 1991; Yie et al. 1995).

There appear to be no significant issues of food safety associated with the expression of coat protein or satellite RNA sequences in crop plants. However, objections to these technologies have been raised from an environmental point of view. Genetic recombination between the virus-derived transgene and virus genes, or the entire virus genome, has been demonstrated. Theoretically, transgene sequences incorporated into the virus genome could generate new, possibly more virulent viruses. Whether such 
recombination could pose a significant risk is unknown, but is highly unlikely given the high background of recombination known to occur naturally in mixed virus infections of both crop and wild plants (Falk and Bruening 1994; Rubio et al. 1999). Under any reasonable scenario, the potential benefits from transgene protection of crops against plant viruses greatly exceed the possible damage from credible risks.

\section{Nontransgenic crop improvement}

Even as new transgenic approaches to crop improvement appear, nontransgenic approaches are having a significant impact. DNA markers are widely used to facilitate crop-breeding programs, augmenting or replacing other types of markers. Plant breeding and hybrid-line production have been improved using new forms of male sterility and population genetics systems.

Entirely new approaches to chemical control of pathogens have been developed which do not require contact between the chemical agent and the pathogen. A benzothiadiazole derivative, CGA 245704, named "Bion," is the first commercially released compound of this type. Bion is effective against fungal diseases, acting as an inducer of a plant defense known as "systemic acquired resistance" (Lucas 1999). A single treatment of wheat seedlings can provide protection for most of the growing season at a dose rate of a few tens of grams (not kilograms, table 1) per acre.

\section{Future in focus: Agronomic traits and crop-production technology}

Plant improvement technology. Of the crop technologies developed in the 20th century, transgenic plants have the greatest potential for making quantum improvements in crop productivity. Our clearest, though still cloudy, view of the changes in crop agriculture likely to proceed in the first quarter of the 21st century is provided by already achieved advances in this and other technologies. The entire genome sequences of rice and the model plant Arabidopsis have nearly been completed. Continual improvements in sequencing technology will allow the major part or the entire sequence to be determined for the genomes of a number of prominent crop plants. Extensive and intensive sequence comparisons ("genomics") will provide important guidance for crop improvement. Even without genome sequences, plant-breeding efforts will

TABLE 3. Examples of methods, results and genetic traits for 21 st-century crops

1. Methods and results for improving crop breeding and propagation Determination of the entire nucleotide sequence of crop plant genomes

Improved selection of traits in breeding using high density DNA marker sets and DNA maps Physiological targets for genetic improvement selected based on patterns of gene expression and large-scale protein functional analyses

Rapid generation of genetic diversity for breeding, e.g., by use of DNA-shuffling technology Improved hybrid production from conditional male sterility

Precision transformation technology, e.g., for plant organelles and for specific nuclear gene replacement

Controlled apomixis (formation of embryos without fertilization; clonal production of seeds)

2. Traits facilitating reduced input agriculture

Broad-spectrum resistance against pathogen, nematode or/and insect species

Non-Bt-based resistance against chewing, piercing or sucking insects

Tolerance to a variety of herbicides

Tolerance to frost, freezing

Tolerance to drought, soil salt and heavy metals

Genetic engineering of photosynthetic efficiency

Genetic engineering of nitrogen fixation

Genetic engineering of improved photosynthetic carbon use and harvest index

"Bioreporters" in crop plants revealing stress or physiological condition to remote sensors

3. Traits facilitating improved crop production

Spatial and temporal control of transgene product accumulation in specific plant parts

Temporal control over seed and/or fruit development and seed germination

Control of plant form and architecture

Extension of the geographic range over which a crop can be grown (appropriate combination of cold tolerance, pathogen resistance, etc.)

increase in efficiency due to physical maps of plant genomes based on easily detected and closely spaced DNA markers. Screening methods that will facilitate rapid plant breeding will be available for reduced cost and rapid introduction of traits, such as durable resistance against evolving pathogens.

Improvements in transformation technology will facilitate insertion of multiple genes and, unlike present methods, will control the site of DNA insertion and thus allow targeted gene replacement. Improved methods for reducing or eliminating expression from specific genes are under development, as well as methods for creating extensive diversity in one or a few genes, for selection of new traits. Tools available and under development, including chloroplast transformation and controllable plant promoters (DNA elements that regulate expression), offer possibilities for localizing genes, gene products and metabolites in the plant. Exclusion of genes from pollen and reversible male sterility will facilitate hybrid seed production and reduce or eliminate the possibility of horizontal gene transfer to other plants.

Regardless of the degree to which plant transformation technology advances, identifying the most useful transgenes to introduce, and the best genetic modifications to perform, remains a great challenge. Continued plant improvement will depend on a much deeper knowledge of plant biochemistry and plant physiology. Newly developed large-scale analyses of genetic interactions and protein function ("proteomics") likely will provide at least part of the needed information.

Other new technologies offer opportunities for more efficient generation of valuable genetic variation and more efficient production of hybrid and other elite seed (table 3, part 1). Two general mechanisms for downregulating gene expression and cell function, co-suppression and programmed cell death, offer new approaches to controlling gene expression in plants that are only now beginning to be explored. 
Environmental impacts. Crop agriculture is among the most environmentally intrusive of human activities, in terms of the area of the earth affected. Biotechnology approaches offer significant opportunities to reduce agricultural inputs (table 3, part 2). Significant potential for reductions in the uses of conventional pesticides is suggested by the data in table 1 . Even for the most formidable limitations to crop production, availability of water, soil quality and climate, it is clear that specific conventional crop traits are partially able to compensate for poor cropping conditions. The $\mathrm{Bt}$ transgene has provided protection against insects that are nearly impervious to chemical sprays. It is reasonable to expect, and some genetic constructions demonstrate (Kasuga et al. 1999), that cleverly designed transgenes may be partially able to overcome some conditions adverse to crop production. Increasing the efficiency of photosynthesis and instilling capabilities for nitrogen fixation into the plant have long been goals, elusive goals, of plant biotechnology. Perhaps less technically challenging are improvements in photosynthetic carbon use and harvest index (Robson et al. 1996).

Crop management would be assisted if plants could act as instruments, indicating the type and degree of biotic and abiotic stress they are experiencing. Reporter genes, capable of responding to signals naturally developed in stressed plants, may be able to provide the desired information as a color change or appearance of fluorescence capable of being monitored remotely. Recombinant DNA methods also offer opportunities for other general enhancements of crop production, in the form of more favorable timing and location of accumulation of crop products and extension of the geographical range over which the crop can be grown (table 3, part 3).

Chemicals and plants. When designed from more sophisticated information about plant biochemistry and physiology, future agricultural chemicals may have significantly improved qualities. Combinatorial chemistry and combinatorial biology, which have revolutionized the pharmaceutical in-

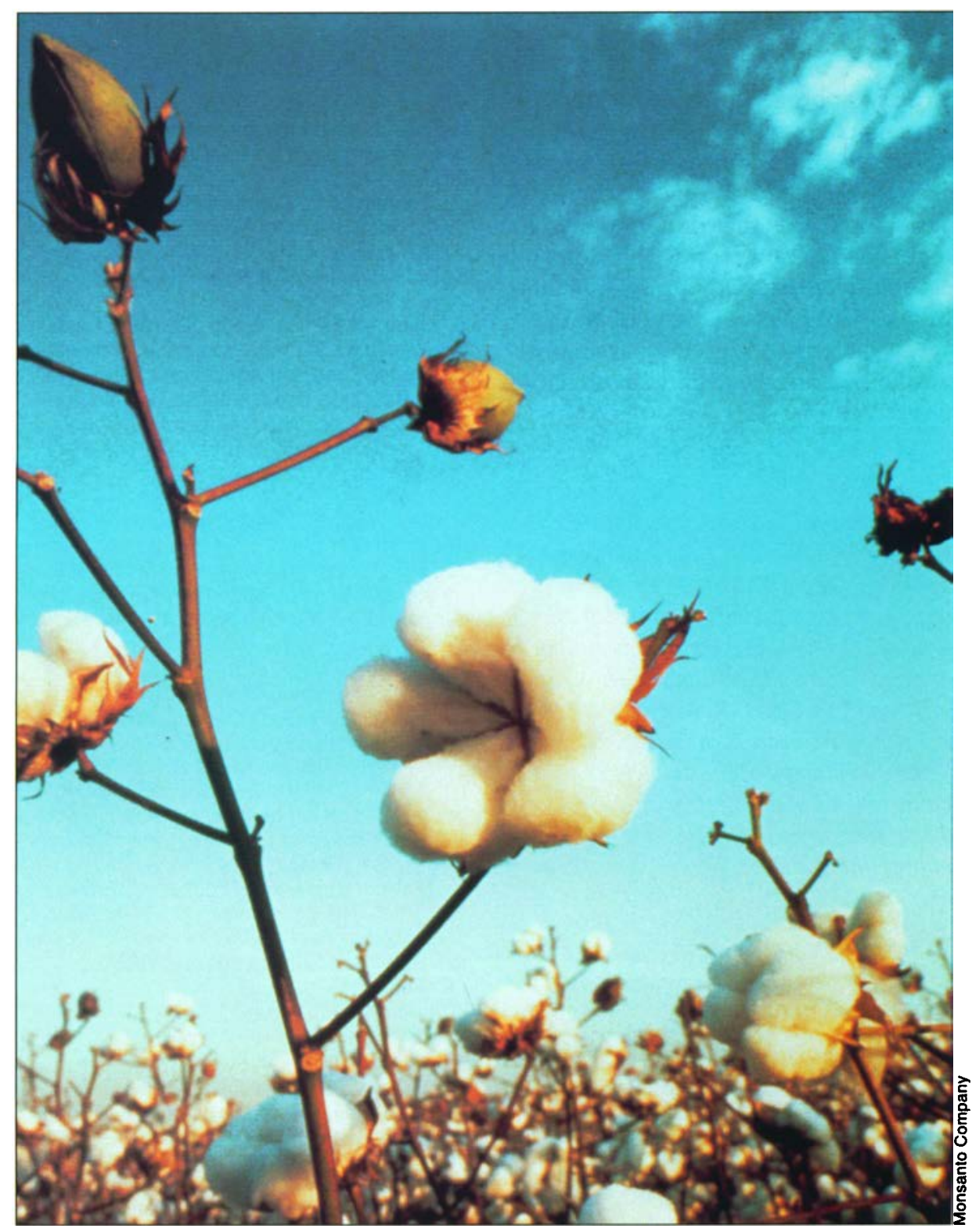

Cotton is currently the only transgenic crop with significant acreage in Callfornia. In 2000 , about 225,600 acres $(24 \%$ of the total cotton acreage) were planted with insectresistant, above, or herbicide-resistant varieties, or plants containing both traits.

dustry, have barely touched crop research and offer approaches to creating new agricultural chemicals. The creation of herbicide-tolerant crops presumably is a precursor to more advanced combinations of chemical and plant molecular genetic approaches in which the crop plant will be modified to take special advantage of a particular chemical regime. Corporate and academic research projects have demonstrated the production in plants of very high levels of specific compounds, even of compounds that may not be compatible with the entire life cycle of the plant. These approaches are based on the use of highly controllable plant promoters and transient ex- pression systems derived from plant viruses (Kumagai et al. 1993). Should such production systems realize significant scale of commercialization, they may be accompanied by some agronomic methods quite different from those now commonly practiced.

Integration with farming systems. We still are in the Model-T era of transgenic crops and biotechnologyenhanced farming. Unfortunately, biotechnology currently is an anathema to many practitioners and proponents of organic farming, biologically integrated farming systems (BIFS) and integrated pest management (IPM). Attitudes may change. Combining transgenic crop plants with these 
farming approaches, sophisticated farm machinery, precision agriculture (see p. 66), and improved agricultural chemicals offers synergistic benefits. A basic example is the combination of a herbicide tolerant crop with a herbicide sprayer that distinguishes plants from other objects in the field and sprays only plants, giving parsimonious herbicide application but effective weed control.

G. Bruening is Professor, Plant Pathology and Biochemist, Experiment Station Department of Plant Pathology and National Science Foundation Center for Engineering Plants for Resistance against Pathogens (CEPRAP), UC Davis. The author is grateful to Larry E. Williams, Theodore Delong, Paul Gepts, R. Michael Davis, Belinda Martineau, Kent Bradford, Valerie Williamson, Jim Lyons and anonymous reviewers for information and/or discussions, and to Peggy Lemaux for providing illustrations.

\section{References}

Ballenger N, Bohman M, Gehlhar M 2000. Biotechnology: Implications for U.S. corn and soybean trade. Agricultural Outlook, USDA Economic Research Service. http:// usda.mannlib.cornell.edu/reports/erssor/ economics/ao-bb/2000/ao270.asc.

Beegle CC, Yamamoto T. 1992. History of Bacillus thuringiensis Berliner research and development. Canadian Entomol 124:587616.

Davis RM, Sorenson EJ, Nunez J. 1999. The Importance of Pesticides and Other Pest Management Practices in US Carrot Production. USDA National Agricultural Pesticide Impact Assessment Program. Washington, DC. $93 \mathrm{p}$.

Estruch JJ, Carozzi NB, Desai N, et al. 1997. Transgenic plants: An emerging approach to pest control. Nature Biotech 15:137-41.

Falck-Zepeda JB, Traxler G, Nelson RG. 2000. Surplus distribution from the introduction of a biotechnology innovation. Am J Agric Econ 82:360-9.

Falk BW, Bruening G. 1994. Will transgenic crops generate new viruses and new diseases? Science 263:1395-6.

Fedak G. 1999. Molecular aids for integration of alien chromatin through wide crosses. Genome 42:584-91.

Ferber D. 1999. GM crops in the cross hairs. Science 286:1662-6.

Fernandez-Cornejo J, McBride WD. 2000. Genetically engineered crops for pest management in U.S. agriculture: Farm level effects. Washington, DC USDA Economic Research Service Agricultural Economics Report No. 786.
Frutos R, Rang C, Royer M. 1999. Managing insect resistance to plants producing $\mathrm{Ba}$ cillus thuringiensis toxins. Critical Reviews in Biotech 19:227-76.

Gebhardt SE, Cutrufelli R, Matthews RH. 1982. Composition of Foods: Fruits and Fruit Juices. USDA Human Nutrition Information Service, Consumer Nutrition Center, Washington, DC.

Gianessi LP, Anderson JE. 1995. Pesticide Use in U.S. Crop Production. National Center for Food and Agricultural Policy, National Pesticide Use Database,Washington, DC. www.ecologic-ipm.com/ncfap_2.html.

Gonsalves D. 1998. Control of papaya ringspot virus in papaya: A case study. Ann Rev of Phytopathology 36:415-37.

Grossman YL. 1993. The Carbon Economy of Reproductive and Vegetative Growth of a Woody Perennial, Peach (Prunus persica [L.] Batsch): Growth Potentials, Respiratory Demand and a Simulation Model. Ph.D. thesis. Botany. UC Davis

Han S. 1987. Miracles of rice. In: Wittwer $S$ (ed.). Feeding a Billion: Frontiers in Chinese Agriculture. East Lansing, Ml: Michigan State University Press. p 139-55.

Haytowitz DB, Matthews RH. 1984. Composition of foods: Vegetables and vegetable products: Raw, processed, prepared. USDA, Nutrition Marketing Division, Human Nutrition Information Service, Washington, DC.

Hyde J, Martin MA, Preckel PV, Edwards CR. 1998. The economics of Bt corn: Adoption implications. Purdue University Cooperative Extension Service, ID-219. West Lafayette, IN.

lannacone R, Grieco PD, Cellini F. 1997. Specific sequence modifications of a cry3B endotoxin gene result in high levels of expression and insect resistance. Plant Molecular Biology 34:485-96.

James C. 1999. Global review of commercialized transgenic crops: 1998. Ithaca, NY: International Service for the Acquisition of Agri-biotech Applications Publication No. 8.

Kasuga M, Liu Q, Miura S, et al. 1999. Improving plant drought, salt, and freezing tolerance by gene transfer of a single stressinducible transcription factor. Nature Biotech 17:287-91.

Kumagai $M H$, Turpen TH, Weinzettl N, et al. 1993. Rapid high-level expression of biologically active alpha trichosanthin in transfected plants by an RNA viral vector. Proceedings of the National Academy of Sciences USA 90:427-30.

Losey JE, Rayor LS, Carter ME. 1999. Transgenic pollen harms monarch larvae. Nature 399:214.

Lucas JA. 1999. Plant immunization: From myth to SAR. Pesticide Science 55:193-6.

Munkvold GP, Hellmich RL, Rice LG. 1999. Comparison of fumonisin concentrations in kernels of transgenic $\mathrm{Bt}$ maize hybrids and nontransgenic hybrids. Plant Disease 83:130-8.

Pease WS, Liebman J, Landy D, Albright D. 1996. Pesticide Use in California: Strategies for Reducing Environmental Health Impacts. California Policy Seminar Research Report (CPS Report) UC Berkeley. 116 p.

Pimentel DS, Raven PS. 2000. Bt corn pollen impacts on nontarget lepidoptera:
Assessment of effects in nature. Proceedings of the National Academy of Sciences USA. 97:8198-9.

Powell-Abel PA, Nelson RS, De B, et al. 1986. Delay of disease development in transgenic plants that express the tobacco mosaic virus coat protein gene. Science 232:738-43.

Robson PRH, McCormac AC, Irvine AS, Smith $H$. 1996. Genetic engineering of harvest index in tobacco through overexpression of a phytochrome gene. Nature Biotech 14:995-8.

Roush RT. 1997. Bt-transgenic crops: Just another pretty insecticide or a chance for a new start in resistance management? Pesticide Science 51:328-34.

Rubio T, Borja M, Scholthof HB, Jackson AO. 1999. Recombination with host transgenes and effects on virus evolution. Molecular Plant-Microbe Interactions 12:87-92.

Sidhu RS, Hammond BG, Fuchs RL, et al. 2000. Glyphosate-tolerant corn: The composition and feeding value of grain from glyphosate-tolerant corn is equivalent to that of conventional corn (Zea mays L.). J Ag and Food Chem 48:2305-12.

Sinclair TR. 1998. Historical changes in harvest index and crop nitrogen accumulation. Crop Science 38:638-43.

Tabashnik BE, Patin AL, Dennehy TJ, et al. 1999. Dispersal of pink boliworm (Lepidoptera: Gelechiidae) males in transgenic cotton that produces a Bacillus thuringiensis toxin. Journal of Economic Entomology 92:772-80.

Tien P, Wu G. 1991. Satellite RNA for the biocontrol of plant disease. Advances in Virus Research 39:321-40.

Traxler G, Falck-Zepeda J. 1999. The distribution of benefits from the introduction of transgenic cotton varieties. AgBioForum 2:94-8.

Tsattaris A. 1996. The development of herbicide-tolerant transgenic crops. Field Crops Research 45:115-23.

US Department of Agriculture. 2000. National Agricultural Statistics Service, Washington, DC. Farmer reported genetically modified varieties www. usda.mannlib. cornell.edu/reports/nassr/field/pcp-bba/ acrg0600.

van Harten AM. 1998. Mutation Breeding: Theory and Practical Applications. Cambridge, UK: Cambridge University Press. 353 p.

Vargas R, Wright S. 1998. Transgenic herbicide-tolerant cotton. California Cotton Review 47:1-3.

Williams LE. 1996. Whole plant sourcesink relationships of selected crops: Grape. In: Zamski E, Schaffer A (eds.). Photoassimilate Distribution in Plants and crops. NY: Marcel Dekker. p 851-81

Wraight CL, Azngerl AR. Carroll MJ, Berenbaum MR. 2000. Absence of toxicity of Bacillus thuringiensis pollen to black swallowtails under field conditions. Proceedings of the National Academy of Sciences USA. 97:7700-3.

Yie Y, Wu ZX, Wang SY, et al. 1995. Rapid production and field testing of homozygous transgenic tobacco lines with virus resistance conferred by expression of satellite RNA and coat protein of cucumber mosaic virus. Transgenic Research 4:256-63. 